Walenty Baluk

https://orcid.org/0000-0003-3295-4872

Maria Curie-Skłodowska University in Lublin

Mykola Doroshko

https://orcid.org/0000-0003-0173-9416

Taras Shevchenko National University of Kyiv, Ukraine

\title{
The role of the Russian Orthodox Church in the context of the Russian-Ukrainian armed conflict
}

Zarys treści: Artykuł analizuje wpływ czynnika religijnego na wewnętrzne procesy konsolidacji państw narodowych na przykładzie Ukrainy oraz na przyczyny i konsekwencje konfliktu rosyjsko-ukraińskiego. Podział ukraińskiego prawosławia na trzy gałęzie (UKP, UKP-KP i UKP-MP) nie pozwolił Cerkwi stać się czynnikiem konsolidującym tworzenie państwa narodowego na niepodległej Ukrainie i generatorem przemian społecznych. Sytuacja może zmienić się na lepsze po utworzeniu Autokefalicznej Cerkwi Prawosławnej Ukrainy w 2018 roku.

Content outline: The article analyses the influence of the religious factor on the internal processes of nation-state consolidation in Ukraine and on the causes and consequences of the Russian-Ukrainian conflict. The division of the Ukrainian Orthodoxy into three branches (UAOC, UOC-KP and UOC-MP) did not allow the Church to become a consolidating factor in the formation of a nation-state in independent Ukraine and a generator of social transformation. The situation may change for the better after the creation of the Autocephalous Orthodox Church of Ukraine in 2018.

Słowa kluczowe: Kościół prawosławny, wojna hybrydowa, konflikt na Ukrainie; Ukraina, Rosja, Patriarchat Kijowski, Patriarchat Moskiewski

Keywords: Orthodox Christianity, "Russian world," hybrid war, Ukraine, Russia, OCU, ROC, Kyiv Patriarchate, Moscow Patriarchate

Religion has greatly influenced, and continues to influence, the formation of cultural and political spaces in societies and has played an important role in the formation of states and nations. Gustav Le Bon believes that many of the historical events related, in particular, to the formation of political and social institutions 
are the result of the influence of religious ideas on these processes. ${ }^{1}$ The relations and interpenetrations of religious and political institutions in the internal and external dimensions of the life of nations and states have always been considered by scholars to be a research subject of considerable practical importance. The religious factor as a significant component of humanitarian relations affects the inner and the outer life of communities.

Polish researcher Danuta Radziszewska-Szczepaniak believes that the dominant false stereotypes in viewing the relationship between religion and politics are: 1) the sacralization of politics and the politicization of religion (blurring the boundaries between politics and religion), 2) the atheization of the politics (eliminating religion from all aspects of human life), 3) the "neutralisation" of religion as a purely private matter of individuals, unrelated to the public sphere. The right approach to the relation between politics and religion, meanwhile, is a model of the "autonomy" that involves the independence of the two domains and their subordination to the interests of the individual and the community, which leads to their mutual influence and interweaving. ${ }^{2}$

The religious factor leans itself to analysis in the vein of the civilisation paradigm or in the terms of political theology, which in one way or another affects domestic and international relations, generating domestic and international processes and conflicts. Well-known sociologist Max Weber believed that the religious factor is the driving force of society and economy. ${ }^{3}$ In turn, German philosopher Karl Schmitt argued that religious consciousness is deeply political and political consciousness is deeply religious. This approach is referred to in social sciences as "political theology."

Religious policy determines, first of all, the attitude of the state towards religious organisations. The religious policy of the state is most often considered a component of internal policy (e.g. Ukraine), however, it may also be an important component of foreign policy (e.g. Russia). ${ }^{5}$

In Russia's hybrid war against Ukraine and in Kyiv's confrontation with the Russian aggression, the religious factor is very much significant. Antoine Arzhakovskyi covered the problem of the Russian-Ukrainian conflict from the perspective of political theology in the book The Discord of Ukraine with Russia. ${ }^{6}$ The French researcher expresses a critical attitude to the civilisation paradigm developed by Samuel Huntington, who viewed civilisations as the highest level of

${ }^{1}$ G. Le Bon, Psychologia. Rozwój narodów, Nowy Sącz, 1999, p. 139.

2 D. Radziszewska-Szczepaniak, "Spór o relacje między polityką i religią. Perspektywa filozoficzna," Nurt SVD, 2 (2017), pp. 257-269.

${ }^{3}$ M. Weber, Gospodarka i społeczeństwo. Zarys socjologii rozumujacej, Warszawa, 2002.

${ }^{4}$ C. Schmitt, Politische Theologie, Berlin, 1922.

${ }^{5}$ R. Michalak, "Polityka wyznaniowa. Zakres zjawiska," Annales UMCS. Sectio K, 26 (2019), no. 1, pp. 24-35.

6 А. Аржаковський, Розбрат Украӥни з Росією: стратегія виходу з піке, Харків, 2015. 
cultural identity among people (the community of language, religion, and territory) and wrote about the religious division of Ukraine into Catholicism (GreekCatholicism) and Orthodoxy. In addition, Huntington argued against the possibility of building a nation-state in Ukraine. His civilisation paradigm, presented in terms of a struggle (collision) of civilisations, in our region is represented as a confrontation between the Western and the Orthodox civilisations. ${ }^{7}$ The arguments of this American scholar, who oversimplified the internal and external processes taking place at the national and international level, have become a useful tool for Russian geopolitics, the Russian Orthodox Church (ROC), and the adherents of the ideology of the "Russian world." 8 In his ideas, they saw the justification of Russia's cultural and religious dominance in the post-Soviet space, particularly in Ukraine.

The "Autumn of Nations" in Central and Eastern Europe led to the completion of the processes of building independent nation-states in some countries, and in others to their first emergence, earlier hampered by the imperial policy of the USSR. One of the tasks of the imperial policy of the Russian Federation is to prevent the formation of nation-states in the post-Soviet space, since the Kremlin understands that the strengthening of new independent states will put an end to Moscow's imperial encroachment. Therefore, in the imperial doctrine of the Russian Federation, the religious factor is one of the most important pillars of state policy.

\section{The church in the politics of the Russian Federation}

In building a modern nation-state, the Russian Federation chose the imperial model of its political and civilisational identity, returning to the imperial traditions of Tsarist and Bolshevik Russia. This model relies heavily on the Uvarov Triad (Autocracy, Orthodoxy, Nationality), in which the Moscow Orthodoxy plays an important role as the "state Orthodoxy." Firstly, it is a model of relations between the state and the church, where the latter is subordinated to the interests of the domestic and foreign policy of the former. Secondly, there is a desire to dominate the world of Orthodoxy, at least de facto, if not in terms of traditions and the canons. The common denominator of one and the other is the concept of "Moscow - the Third Rome." This, in turn, influences the imperial component of Russian state and church traditions.

\footnotetext{
7 S. Huntington, Zderzenie cywilizacji i nowy kształt ładu światowego, Warszawa, 1997.

${ }^{8}$ Ideology of the "Russian world": 1) geopolitical authenticity, namely seeking to reinstate its natural borders (A. Dugin, A. Stoliarov, V. Tsymbursky), 2) geo-economic space (P. Shchedrovitsky, T. Poloskov, V. Skrynnik), 3) an ethno-cultural community of people with access to the Russian language and culture (V. Nikonov, N. Narochnitskaya, V. Tyshkov), 4) Orthodox civilization understood to encompass Holy Russia, as well as Russia, Belarus, Ukraine, and Moldova (С. Кочеров, “Русский мир: проблема определения," Вестник Нижегородского университета им. Н.И. Лобачевского (2014), по. 5, pp. 163-167).
} 
American researcher Henry R. Guttenbach, examining the origins of Russian imperialism, pointed to the connection between religion and Russian expansionism. The scholar emphasised that in their minds, Russians were not so much Slavs (until the 19th century such self-identification was underdeveloped) as Orthodox Christians. The formation of the Russian Empire on the foundation of the Moscow State took place in the name of Orthodoxy. Religious motives (opposition to the Catholics in the West and the Muslims in the East, the expansion of geographical boundaries of Orthodox Christianity) underpin the so-called unification of Russian lands, the annexation and seizure of foreign territories. ${ }^{9}$

The definitive return of the Russian Federation to imperial politics at the initial stage of Vladimir Putin's rule, especially after the Orange Revolution in Ukraine, drew the attention of the Russian leadership to the political ideology of the ROC. The 2004 Ukrainian events were a consolidating factor for the state and the church in Russia around the idea of "Russian civilisation" and Russia's particular path of development. The authorities in Russia could not help but notice that in Ukraine, the church (UOC-MP) had proven itself to be an influential socio-political force supporting the pro-Russian candidate. ${ }^{10}$ This contributed not only to the return of Russia to the Byzantine model of a "symphony" of state and church, but also to the use of ROC structures in the post-Soviet space to spread the ideology of the "Russian world." This is meant to protect the so-called canonical territories of the ROC, with the Russian minority in these countries used as a significant factor of influence (the "fifth column").

The ideology of the "Russian world" is supported not only by the Russian state but also by the Russian Orthodox Church. Patriarch Kirill calls the "Russian world" a separate civilisation which comprises Russians, Belarusians, and Ukrainians, as well as other non-Slavic peoples, if only they recognise the spiritual and the cultural foundations of the "Russian world." 11 The ROC identifies the "Russian world" with its so-called canonical territory, which once coincided with the borders of the Russian Empire. It encompasses all the people living in the locations where its congregations are situated and where its flock lives. After all, the "Russian world" is a civilisation with an ideological and theological component, in which the ROC plays a key role in creating a "symphony" with the authorities. ${ }^{12}$

9 Г.Р. Гуттенбах, “Витоки російського імперіалізму," in: Російський імперіалізм, ed. Т. Гунчак, Київ, 2010, pp. 33-35.

10 С. Филатов, “Традиционные религии, «русская цивилизация» и суверенная демократия,” in: Религия и конбликт, ed. А. Малашенко, С. Филатов, Москва 2007, pp. 15-40.

11 “'Ruski świat' nie oznacza budowania imperium rosyjskiego?," Fronda.pl (8 September 2014), http://www.fronda.pl/a/ruskiego-swiata-nie-oznacza-budowania-imperium-rosyjskiego,41418. html (accessed: 11 September 2014).

12 Т. Борозенец, Русский мир и РПЦ (попытка прояснения смыслов), https://www.religion. in.ua/zmi/ukrainian_zmi/6940-russkij-mir-i-rpc-popytka-proyasneniya-smyslov.html (accessed: 2 August 2020). 
Firstly, the ideology of the "Russian world" as understood by the Russians consists in latent preservation of the ROC borders of the Russian Empire on the basis of its so-called canonical territory, which in modern conditions means an area of exclusively Russian interests. Secondly, citizens of other countries (Ukraine, Belarus, Moldova) are bound to the "Russian world" (ROC and RF) on the basis of the religious (Orthodoxy) and the secular (language and culture) criterion. Thirdly, the ties of the citizens of these countries with their own state are weakened, and reinforced instead is their loyalty to the ROC and Russia, which poses a direct threat to national security. The policy of Russia is well-reflected in the words of the Eurasian doctrine of theorist Aleksandr Dugin, who in his famous book The Foundations of Geopolitics wrote that Russia should counteract the formation of nation-states, administrative structures with permanent borders, and forms of power structure in the post-Soviet space. ${ }^{13}$

The ideology of the "Russian world" has become not only a kind of a "Monroe Doctrine" of the Russian Federation, but also a cause for the erosion of sovereignty and territorial integrity of post-Soviet states. Vladimir Putin adopted the so-called "Brezhnev Doctrine" (the doctrine of limited sovereignty of CEE states), which envisaged interference in the internal affairs of Central and Eastern European countries in order to protect socialist values. On this basis, today's Russian Federation has formed and implemented the Putin Doctrine with the help of the ROC, which is based on interfering in the internal affairs of post-Soviet countries to protect the "Russian world" (ethnic Russians and the ROC). It is a doctrine that underlies not only the Orthodox civilisation, but also the imperial thinking and Russian politics, based on revisionism and expansionism in the spirit of the "harvesting Russian lands." Nowadays, more and more calls can be heard in Russia for the revival of the Russian state within its historical borders, that is "Great Russia" or historical Russia. After the collapse of the USSR, these concepts were adopted by a number of writers and thinkers of the Orthodox Christian, great-power, and imperial circles in Russia. ${ }^{14}$ In his revisionist speeches, these terms are also used by Putin himself, in particular in his article Russia: The National Question. ${ }^{15}$ The Russian president has repeatedly emphasised that Russian Orthodoxy is a key element of the Russian cultural code. ${ }^{16}$

13 А. Дугин, Основы геополитики. Геополитическое будущее России, Москва, 2000, pp. 348-349.

${ }^{14}$ V. Averianov, S. Baburyn, A. Vasserman, T. Honcharov, H. Znamenskyi, S. Epyshev, Y. Yhnatov, S. Kortunov, M. Leontev, V. Makhnachev, V. Medynskyi, E. Kholmohorov (А. Илларионов, “Границы «большой, или исторической, России» по В.Путину," Радиостанция «Эхо Москвы»" [24 July 2019], https://echo.msk.ru/blog/aillar/2469765-echo/ [accessed: 20 September 2020].).

15 В. Путин, “Россия: национальный вопрос," Независимая газета (23 January 2012), http:// www.ng.ru/politics/2012-01-23/1_national.html (accessed 24 January 2020).

16 “Интервью Оливеру Стоуну," Kremlin.ru (19 July 2019), http://kremlin.ru/events/president/ news/61057 (accessed: 24 September 2020). 
In the context of not only statistics but also geopolitics, it should be borne in the mind that according to the Russtat data for 2018, the ROC (the Moscow Patriarchate) comprised 18,550 religious organisations in Russia, and taking into account the parishes located abroad - 38,649 temples. ${ }^{17}$ In particular, in Ukraine (UOC-MP) the Moscow Patriarchate has more than 12,000 parishes, ${ }^{18}$ in Belarus (the Belarussian Exarchate of the Moscow Patriarchate) - 1,612, ${ }^{19}$ in Moldova (Moldavian-Chisinau Metropolitanate of the ROC) $-1,231 .{ }^{20}$ The statistics show that by losing the UOC-MP parishes, the Russian Orthodox Church would lose its status as the largest Orthodox church in the world. In total, taking into account about 7,000 parishes of the Orthodox Church of Ukraine (OCU), the Kyiv Church is the largest Orthodox Church in the world in the terms of numbers.

Table 1. Poll asks Ukrainians: To which Orthodox Church do you belong? / (\%)

\begin{tabular}{|l|c|c|c|c|c|c|c|c|}
\hline & $\mathbf{2 0 0 0}$ & $\mathbf{2 0 1 0}$ & $\mathbf{2 0 1 3}$ & $\mathbf{2 0 1 4}$ & $\mathbf{2 0 1 8}$ & $\mathbf{2 0 1 9}$ & $\mathbf{2 0 2 0}$ \\
\hline \multicolumn{7}{|c|}{ About 62-70\% of the population declared adherence to Orthodox Christianity. } \\
\hline UOC-KP & 18,4 & 22,1 & 25,9 & 31,9 & 42,6 & 11,9 & 3,7 \\
\hline UAOC & 1,3 & 0,9 & 0,8 & 0,7 & 1,8 & - & - \\
\hline OCU & - & - & - & - & - & 20,3 & 29,8 \\
\hline UOC-MP & 14,0 & 34,5 & 27,7 & 24,8 & 19,1 & 16,3 & 21,7 \\
\hline Just Orthodox & 54,6 & 37,9 & 40,8 & 39,8 & 34,8 & 46,6 & 43,3 \\
\hline
\end{tabular}

Source: Osoblyvosti relihiynoho i cerkovno-relihiynoho samovyznachennya hromadyan Ukrainy: tendencii 20002020 rr. (Informaciyni materialy), https://razumkov.org.ua/uploads/article/2020_religiya.pdf (accessed: 10 February 2021).

Certain regional differences can be noticed in terms of religion. The network of religious communities of the Moscow Patriarchate covers all regions of Ukraine almost evenly. During 1992, as a result of the Moscow Patriarchate's interference in the affairs of the Ukrainian Orthodox Church, it was split into UOC-MP and UOC-KP. The network of religious communities adhering to the UOC-KP is most extensive in Kyiv and Kyiv region, Ivano-Frankivsk, Volyn, and Ternopil regions. The UAOC is best represented in Lviv, Ivano-Frankivsk, and Ternopil regions. Catholic religious communities prevail in Western Ukraine. More than a third

17 “Православие в цифрах: сколько храмов и духовных организаций в РПЦ?," ГРОШ ЖУРНАЛ (29 May 2019), https://grosh-blog.ru/pravoslavie-v-cifrah-skolko-v-hramov-i-duhovnyh-organizacij-u-rpc/ (accessed: 24 September 2020).

18 Українська правоставна церква (Московський патріархат), http://orthodox.org.ua/ (accessed: 25 September 2020).

19 “Белорусский Экзархат," Официальньй портал Белорусской православной Церкви, http:// www.church.by/belorusskiy-ekzarhat/ (accessed: 25 September 2020).

20 Православная Церковь Молдовы, https://ru.mitropolia.md/ (accessed: 25 September 2020). 
of Greek Catholic religious communities are located in Lviv region and another third of them - in Ternopil region and Transcarpathia. The study of geography of religion in Ukraine has shown a revitalisation of the Moscow Patriarchate with the active support of the Russian Orthodox Church and the public authorities. ${ }^{21}$

The ROC is projecting its spiritual influence widely beyond Russia's borders and has traditionally been a key soft-power tool for the Kremlin. Under Putin, the role of spirituality and Orthodoxy has increasingly been elevated to that of a mythical unifier of all Slavic people in the "Russian world." In 2012, Patriarch Kirill of Moscow adopted a neutral stance towards Russian military incursions into Ukraine, including Crimea, amid concerns about losing followers. Nevertheless, a number of Russian Orthodox priests in eastern Ukraine have openly sided with pro-Russian separatists, blessing them and letting them store ammunition in churches. The Ecumenical Patriarch of Constantinople granted the Orthodox Church of Ukraine (OCU) autocephaly on 5 January 2019, formalising its split from the ROC. The move followed an intensified Ukrainian campaign to obtain religious independence and thereby reduce the influence of the ROC, which plays a key role in the Kremlin's identity politics in the region. ${ }^{22}$

President Vladimir Putin and the ROC share a sacralised vision of Russian national identity and exceptionalism. The essential elements of this ideology are: integrative patriotism, sovereign democracy, and Orthodox Christianity (uniting East Slavic people). ${ }^{23}$

For the Russian imperial idea that underlies the Russian state and the ROC today, the emergence of a unified and autocephalous Ukrainian Orthodox Church poses a direct geopolitical threat. The formation of separate churches, as shown by the experience of several CEE countries, also contributes to the formation of nation-states, which is an undesirable phenomenon for the Russian geopolitics.

Russian analyst Alexei Malashenko writes that the politicisation of the ROC has long gone beyond what is possible. With their interference in secular affairs, the Patriarch and the ROC try not so much to solve social problems but to increase their political weight in every possible way by supporting and legitimising power. ${ }^{24}$

${ }^{21}$ O. Lyubitseva, "Research on the geography of religion in Ukraine," Peregrinus Cracoviensis, 25 (2014), no. 3, pp. 91-100.

${ }^{22}$ N. Bentzen, "Ukraine: Religion and (geo-)politics Orthodox split weakens Russia's influence," EPRS | European Parliamentary Research Service (February 2019), https://www.europarl.europa. eu/thinktank/en/document.html?reference=EPRS_BRI(2019)635525 (accessed: 25 September 2020).

${ }^{23}$ J.C. Antúnez, The Role of Religion and Values in Russian Policies: The Case of Hybrid Warfare, https://global-strategy.org/the-role-of-religion-and-values-in-russian-policies-the-case-of-hybridwarfare/ (accessed 25 November 2020).

24 А. Малашенко, “Религия в России: политизация и размежевания," Московский Центр Карнеги (3 September 2021), https://carnegie.ru/2012/09/03/ru-pub-49253 (accessed: 23 November 2020). 
This tradition of the Russian Empire, which is based on "symphonic" state-church relations, ${ }^{25}$ today influences the formation of political culture in the Russian Federation.

\section{The role of the church in the formation of a nation-state in Ukraine}

After the collapse of the Soviet Union in 1991, the process of political transition in Ukraine took on a peculiar form. In most Central and Eastern European countries, the process of forming nation-states had been completed in the interwar period. Therefore, changes in these countries after the fall of communism took place on two levels - political and economic (democracy/market). Ukraine has a much more complicated path of transformation in four dimensions (democracy/market/state/ nation). ${ }^{26}$ In the context of our study, we focus on the process of nation-building and state-building from the perspective of the nation-state construct.

Well-known Ukrainian scholar and politician Serhiy Shelukhin believed that the church must, first and foremost, protect and uphold the interests of its own nation and state. Therefore, in ecclesiastical and religious affairs, Ukraine must get rid of "alien influences." He was aware that it would be difficult to build an independent state without a Ukrainian (autocephalous) church. ${ }^{27}$ The founder and theorist of Ukrainian conservatism, Viacheslav Lipinski, wrote that religion is a positive (good) value in political and social life. Everyone who wants to strengthen the organisational unity of their society (nation and state) must support religion in every possible way. Lay people need religion and the church during the struggle for, the formation, and the development of a nation-state. At the same time, Lipinski wrote about the autonomy of ecclesiastical and secular power in the state and about the equality of all Christian denominations. For the Ukrainian ideologue of Polish descent, autocephaly was not a necessary element of the nationstate construct, which needed to be implemented at any cost, with the Ukrainian culture having to adapt Eastern and Western influences to its needs. For Lipinski, who promoted the idea of forming a Ukrainian political nation, the issues of patriotism and loyalty to the state and the formation of state consciousness among Ukrainian citizens of Orthodox, Catholic, and Protestant denomination were more important. ${ }^{28}$

25 А. Полянцева, “«Симфония» властей в Византии и России как преемницы Византийской империи,” Научный журнал КубГАУ, 118 (2016), nо. 4.

${ }^{26}$ T. Kuzio, "Transition in Post-Communist States: Triple or Quadruple?," Politics, 21 (2001), no. 3 , p. 174.

27 Я. Турчин, “Сергій Шелухін про роль Церкви у державотворчих процесах України," Українська національна ідея: реалії та перспектива розвитку (2003), no. 14, p. 83.

${ }^{28}$ W. Lipiński, Religia i Kościół w dziejach Ukrainy, Przemyśl, 1999, pp. 47, 49, 84. 
It is impossible to speak of the existence of a state church in Ukraine due to various circumstances, including the numerous divisions undergone by the Ukrainian Orthodoxy, beginning with the split into Uniates and the Orthodox (1596), later followed by the formation of the Ukrainian Autocephalous Orthodox Church, unrecognised by the world Orthodoxy (1921), and nowadays, the division of the Ukrainian Orthodox Church into the Kyiv and Moscow Patriarchates (1992). Such a model of church-state relations has taken shape in Greece, where the Hellenic Orthodox Church has the status of a state church. In fact, the ROC has the same position in Russia, though not supported by any legislative acts. In Ukraine, we can speak about a national church (in the ethno-cultural sense) or nationally oriented churches when referring to the Ukrainian Greek Catholic Church and the UAOC, which had limited territorial influence, and from the early 1990s about the UOC-KP.

The concept of a national church is not the same as that of a state church. The former is a component of the spiritual and cultural development of a nation, the second - a component of a socio-political process. "National" does not mean one for the whole nation. ${ }^{29}$ However, when we consider a nation in the political rather than in the ethnic dimension, as a nation-state, we arrive at a formula by which the national church influences the spiritual-cultural life and the socio-political processes in the state. This description could apply to the Autocephalous Orthodox Church of Ukraine (OCU) and the UGCC, which in the future may unite under the Kyiv Patriarchate based on the tradition of the Kyiv Church.

The Ukrainian Orthodox Church of the Moscow Patriarchate in its essence and content cannot claim to be a national and a state church or to be a unifying factor of the Ukrainian people (political nation) and state. On the contrary, being a part of the ROC, it adheres to the ideology of the "Russian world," which denies the existence of the Ukrainian nation-state, and during the Russian-Ukrainian war, indirectly and sometimes openly sided with the aggressor - Russia. The UOC-MP did not openly condemn the aggressor, but at the same time was disloyal to the Ukrainian state.

In terms of state-church relations (legal context), there are usually three categories of states: 1) states that have a dominant religion and church (England Anglicanism, Spain and Italy - Catholicism, Greece - Orthodoxy), 2) states with formal equality of all religions and churches without separation of the church from the state (Austria, Germany, etc.), 3) states in which the church is formally separated from the state (USA, France, etc.). ${ }^{30}$ In independent Ukraine, the third type of state-church relations was formed, where the church was formally separated from the state and from public schooling (Articles 5 and 6 of the Law

\footnotetext{
29 А. Колодний et al., Історія релігії в Украӥні, Київ, 1999, pp. 691-694.

30 Ю. Римаренко (еd.), Мала енизиклопедія етнодержавознавство, Київ 1996, р. 464.
} 
on Freedom of Conscience and Religious Organisations). ${ }^{31}$ At the same time, a multi-denominational religious environment has emerged in Ukraine, breeding inter-denominational conflicts. Before the Revolution of Dignity, Ukrainian researcher Yurii Balukh wrote about the religious conflicts in the country, pointing to the main lines of confrontation: 1) Orthodox - Catholics (all branches of Ukrainian Orthodoxy on the one hand, and Roman and Greek Catholics on the other), 2) various denominations within Orthodoxy (UOC-MP, UOC-KP and UAOC), 3) internal contradictions in other denominations, 4) contradictions between traditional religions and non-religions. ${ }^{32}$

\section{Ukrainian Orthodoxy in Russia's hybrid war against Ukraine}

Establishing Ukrainian Orthodoxy subordinate to the Moscow Patriarchate is a strategic goal of Russia and the ROC, the fulfilment of which would help retain its influence in Ukraine, not so much religious but political and cultural. The Orthodox Church in Ukraine is regarded by the Russian secular and ecclesiastical authorities as an integral part of the imperial policy and the geopolitical project of the "Russian world." At the initial stage in the development of this concept, it seemed that it would be used by Moscow as an element of its soft power policy, but later it became clear that it started to be applied in Vladimir Putin's policy towards Ukraine as an element of smart power and even hard power. Leading American sociologist Jose Casanova argues that religion played a huge role in the events of 2014 and the Russian-Ukrainian conflict, because in Ukraine, the interests of the Kremlin's imperial policy coincided with those of the ROC project. ${ }^{33}$ Although the Russian-Ukrainian conflict does not have religious grounds, Patriarch Cyril tried to present it as such in 2014, placing it in the context of the "war for faith."

In his interview, Jose Casanova points out that a system of state-church relations was formed in Ukraine in which all religions have equal rights and compete with each other. This type of a relationship influences the society at large and promotes pluralism in religious life, but it does not favour the unification of the nation. The scholar believes that one of the outcomes of this type of relationship was that during the Revolution of Dignity, all religious communities in the country remained close to the citizens - the Orthodox, Greek Catholics, Protestants, Jews, and Muslims. ${ }^{34}$ However, during the Revolution of Dignity and

31 “Закон про свободу совісті та релігійні організації," Відомості Верховної Ради УРСР (ВВР), 1991, no. 25, p. 283 (зі змінами та доповненням).

32 В. Балух, “Міжконфесійні конфлікти: причини, типологія та шляхи подолання," Релігія ma соиіум (2016), no. 3-4, p. 125.

33 Х. Казанова, “Я не вірю в нації, але вірю в силу духа українців,” Дзеркало тижня (15 Мау 2015), https://zn.ua/ukr/amp/columnists/ya-ne-viryu-v-naciyi-ale-viryu-v-silu-duhu-ukrayinciv-172892_.html (accessed: 20 November 2020).

${ }^{34}$ Ibid. 


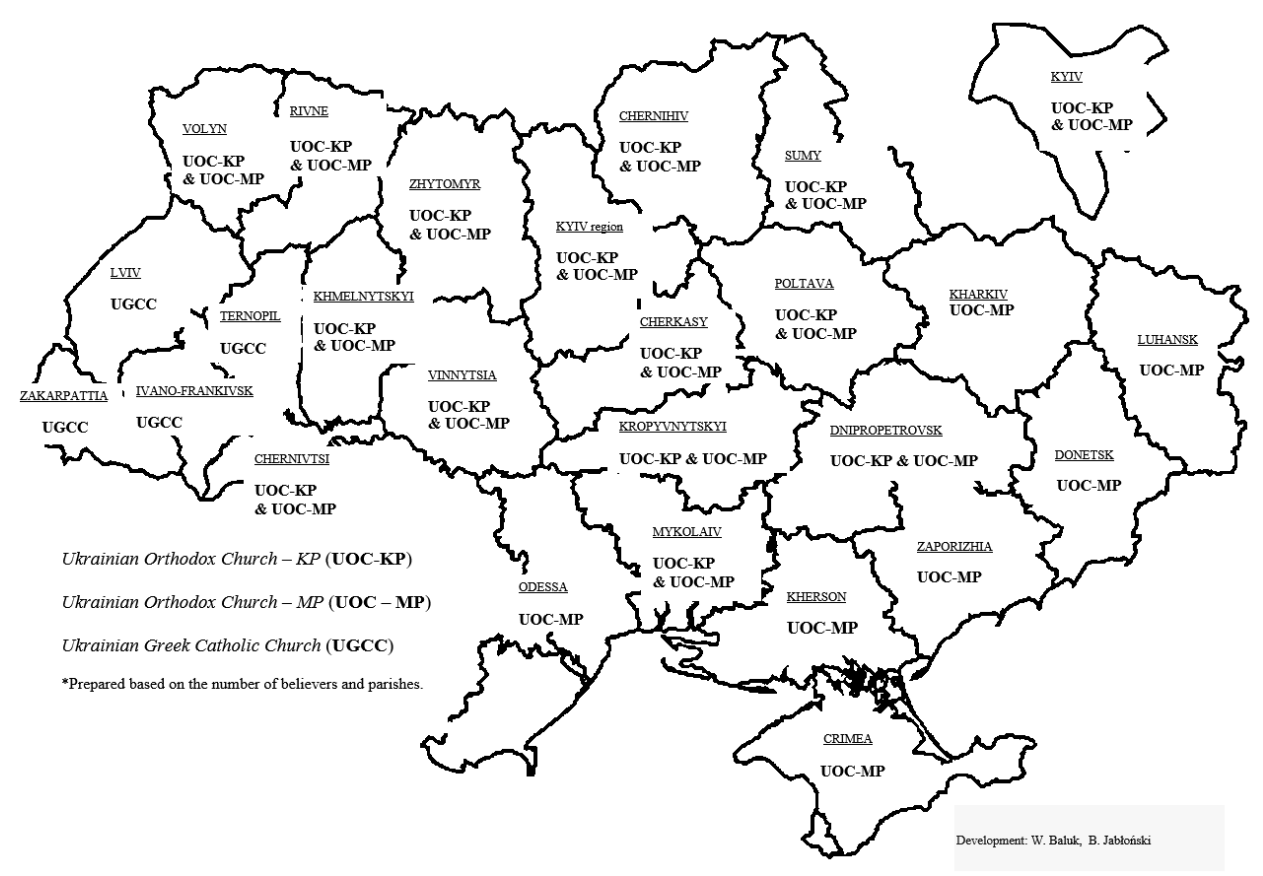

Regional Dominance of Religion in Ukraine (2018)

the Russian-Ukrainian armed conflict, the hierarchy and most of the clergy of the UOC-MP did not generally support the Ukrainian state and society, which was seeking change and a European path of development. While most denominations in Ukraine contribute to the formation of a civic society and seek to build the liaison with it, the UOC-MP largely supports the concept of the "Russian world," which imposes the dominance of Russian (Moscow) Orthodoxy as the only Russian, blessed, canonical Orthodox Church. In his analysis, the American scholar concludes that the Moscow Patriarchate is becoming de facto the sole legitimate religious organisation in Crimea, Donetsk, and Lugansk, where other denominations face major struggles. ${ }^{35}$

In contrast to the Russian Federation, a different type of state-church relations was formed in Ukraine, where it was difficult to implement the formula of "symphony" of state and church power. The government at least formally sought to be equidistant from all Orthodox churches in Ukraine (UOC-MP, UOC-KP, and UAOC). After the collapse of the USSR, the former communist nomenklatura remained in power in independent Ukraine at the central and regional level, which for the most part retained an atheistic attitude to religion. However, the authorities could not help but notice the growing importance of the church's role in the public life and were unable to resist the temptation to use it in the political

${ }^{35}$ Ibid. 
process. The leaders of the Ukrainian Orthodox Church, both of the Moscow and Kyiv Patriarchates which grew out of the tradition of "state Orthodoxy," naturally sought to form a closer relationship with the authorities and the state. However, the Russian model of the "symphony" of relations between the authorities and the church was not implemented in Ukraine for two reasons. First, Ukrainian Orthodoxy is divided into three branches (UAOC, UOC-MP, and UOC-KP). Secondly, after the country gained independence, the state-building processes continued but no nation-state was formed. Therefore, the Orthodox clergy built relationships with the central and regional nomenklatura, which was then replaced by oligarchs. This new Ukrainian class focuses predominantly on exploiting the economic and political potential of the state for its own purposes, and is therefore not interested in building a strong and democratic nation-state.

At the official level, the church in Ukraine does not participate in the political life of the country, but the formal and informal links between the leading denominations and the state apparatus as well as oligarchic structures have existed since independence and have been steadily tightening over the years. A confirmation of this claim can be easily found by analysing the electoral process and the "electoral map" of Ukraine. In particular, the UOC-MP had a decisive role in the eastern and southern regions of Ukraine, and a significant influence in the central regions, while the structures of the UOC-KP were of considerable importance in the central regions and in Volyn. The UAOC and the UGCC, in turn, influenced the inhabitants of the western regions. Indicative in this context is the establishment of a kind of "coherence" of the actions of local state administration and regional church units manifesting in various issues of social life and in the construction of church infrastructure. ${ }^{36}$ The same process later took place in the relations between the church and oligarchic structures.

It was mainly through this type of a relationship that the UOC-MP developed its institutional structure, beginning to claim a leading role in the Ukrainian society and in its relations with the authorities. Other branches of Ukrainian Orthodoxy (UOC-KP and UAOC) have been less reliant on the phenomenon of "coherence" in building their infrastructure, in particular in connection with the formation and clarification of relations in the unification process of the two churches, which quickly ended in divorce.

The situation began to change during the Orange Revolution, when significant changes took place in the Ukrainian society. In general, the Church of the Moscow Patriarchate (UOC-MP) in Ukraine supported pro-Russian forces and the "party of power" led by Viktor Yanukovych, who did not hide his affiliation to the UOC-MP. Other branches of Ukrainian Orthodoxy and the Greek Catholics leaned more towards the opposition and Viktor Yushchenko, who declared his

36 У. Яцишин, “Роль церкви і духовенства у виборчому процесі України,” Українська національна ідея: реалії та перспективи розвитку (2011), nо. 23, pp. 128-133. 
affiliation to the UOC-KP. In this way, the 2010 presidential election in Ukraine saw the emergence of the process of the politicization of religion and sacralization of politics. After claiming victory in the Orange Revolution and the presidential election, Viktor Yushchenko granted his symbolic support to the UOC-KP and intensified the autocephalic process of the Ukrainian Church. In an act of revenge, Viktor Yanukovych and the pro-Russian forces and oligarchic structures began to openly support the UOC-MP in the church-power relations and began to fight for power in the church itself.

The UOC-MP in Ukraine is not connected with the state and the authorities (although attempts to introduce the Russian model of state-church relations were made during the rule of V. Yanukovych), as is the case in Russia with the ROC. Firstly, a somewhat different model of state-church relations has emerged in Ukraine. Secondly, much of the clergy and lay members of the UOC-MP do not feel a connection to the Ukrainian state, but rather identify with the ideology of the "Russian world," which denies the existence of Ukraine as a nation-state, and views it as a country (not a state) of Malorossiya, itself a part of the "Russian Orthodox civilisation" in which Moscow and Russia are of key importance.

Close ties between the church (UOC-MP) and the authorities were established in Ukraine during the rule of the President Viktor Yanukovych, ${ }^{37}$ who was openly supported by the Moscow Patriarchate. The inauguration of the president in 2010 was attended by Moscow Patriarch Kirill, who conducted a prayer service at the Kyiv-Pechersk Lavra with the participation of the president and visited Ukraine twice more the same year. The President regularly visited the UOC-MP and financed the restoration and construction of UOC-MP temples from the State Treasury. ${ }^{38} \mathrm{He}$ also granted state distinctions to the apologists of the "Russian world." On the occasion of Independence Day, he presented a state award to Metropolitan of Odessa and Izmail Agafangel, leader of the Ukrainian-phobic wing in the UOC-MP. In his turn, Patriarch Kirill awarded V. Yanukovych with the Order of the Saint Apostolic Prince Vladimir and presented church awards to various ministers and oligarchs, in particular to Y. Boyko and D. Firtash. ${ }^{39} \mathrm{His}$ entourage worked to remove Metropolitan Volodymyr (Sabodan), who did not agree to the involvement of the church in politics, from his position.

In 2013-2014, slipping the attention of outside observers of Ukrainian politics, a struggle was underway for the leadership in the UOC-MP between a powerful pro-Russian wing and a less influential pro-Ukrainian one. Participating in the election of the new leader were not only Ukrainian politicians and oligarchs, but also the Patriarch of Moscow and the Kremlin. The pro-Russian wing eventually

37 О. Крамар, “Влада та іï церква,” Тиждень.иа (14 January 2011), https://tyzhden.ua/Politics/6562 (accessed: 15 November 2020).

38 Національна безпека і оборона (2013), no. 1, p. 3.

39 “Кирило помолився за Януковича і нагородив Бойка з Фірташем," Украӥнська правда (2 October 2011), https://www.pravda.com.ua/news/2011/10/2/6634061/ (accessed: 23 August 2020. 
emerged victorious, and Metropolitan Onufrii, considered a moderate supporter of the "Russian world," was elected the head of the church. ${ }^{40}$ This was sufficient to give boost to the UOC-MP ideology of the "Russian world" and led to the events called the "Russian spring," which were a continuation of the Russian aggression against Ukraine in the East.

Religious studies expert Dmytro Horievoi notes that during the RussianUkrainian armed conflict, it was the UOC-MP that: 1) called to betray Ukraine and move to the side of Russia, 2) blessed Russian weapons used against Ukraine, 3) cooperated with the Russian Armed Forces, 4) sanctified prisoners, 5) blessed the leaders of terrorist organisations ("DPR," "LPR"), 6) engaged in espionage for the benefit of these organisations and Russia, 7) anathemised the Ukrainian authorities and disrupted mobilisation in the army, 8) refused to honour the people killed in Ukraine, 9) denied the existence of a Ukrainian nation, and 10) did not acknowledge Russian aggression against Ukraine, instead presenting the Russian-Ukrainian armed conflict as a civil (fratricidal) war in Ukraine to please the interests of the Russian Federation. ${ }^{41}$

In an interview, Metropolitan Onufrii claimed that the ongoing conflict in eastern Ukraine was a civil, fratricidal war. To drive this point home, he even drew a comparison between the 1917 Revolution in Russia and the 2013-2014 Revolution of Dignity, and called for reconciliation that would help to preserve the integrity of the state. ${ }^{42}$ The Metropolitan did not say a single word about the fratricidal war waged by one Orthodox people (Russians) against another (Ukrainians) or the annexation of Crimea, nor did he condemn Vladimir Putin's aggressive policies. On the contrary, when Russia was recognised at the official level as an aggressor in Ukraine, Metropolitan Onufrii received the honours from the Moscow Patriarch $(2014,2019)$. There are many other examples of disloyalty of the UOC-MP hierarchs towards the Ukrainian state. One of these was Metropolitan of Simferopol and Crimean Lazar being awarded with an engraved watch by the President of Russia for loyalty to the Motherland (Russia). ${ }^{43}$ A significant number of priests of the UOC-MP have blessed Russian terrorists (e.g. the blessing

40 А. Юраш, “В УПЦ МП йде боротьба між проросійськими і проукраїнськими групами, які хочуть бачити свого кандидата на чолі церкви," UkrMedia інтернет-газета, https://ukr. media/206732/ (accessed: 20 August 2020).

41 “Релігієзнавець пояснив, чому УПЦ (МП) не можна залучати до примирення," Cerkvarium. org (25 January 2020), https://cerkvarium.org/publikatsii/monitorynh-zmi/religieznavets-poyasniv-chomu-upts-mp-ne-mozhna-zaluchati-do-primirennya (accessed: 24 August 2020).

42 "Митрополит Онуфрій про війну на Сході," СПЖ “Союз православных журналистов" (14 July 2015), https://spzh.news/ru/zashhita-very/25719-mitropolit-onufrij-pro-vijnu-na-skhodi-o-vojne-v-donbasse (accessed: 24 September 2020).

43 “Путін нагородив іменним годинником митрополита УПЦ-МП у Криму," РІСУ - Релігійноінформаційна служба України (17 May 2019), https://risu.org.ua/ua/index/all_news/community/ religion_and_policy/75844/ (accessed: 23 September 2020). 
of I. Girkin), ${ }^{44}$ cooperated with the Russian occupation forces in Crimea, or hid terrorists and weapons (e.g. the Kyiv-Pecherska Lavra and the Sviatohirska Lavra). ${ }^{45}$

Speaking to protesters, the deputy of the Kyiv-Pecherska Lavra, Bishop Pavlo, stated that the annexation of Crimea to Ukraine in 1954 had been "illegal" and that the peninsula had never belonged to Ukraine. Asked about whom Ukraine was fighting in Donbass, Bishop Pavlo avoided a direct answer and said that it was unknown who was at war with whom. He specified that there was no presence of the Moscow Patriarchate in Ukraine, but there was the Russian Orthodox Church. ${ }^{46}$ The leadership of the Crimean Diocese of the UOC-MP in Sevastopol periodically consecrates the flags of Russian warships and celebrates the "reunification with Russia." At the end of December 2017, Crimean Metropolitan Lazar presented the Order of the Russian Orthodox Church to Sergei Aksyonov, who had betrayed Ukraine. ${ }^{47}$

Through its religious and social activities, the UOC-MP promotes the ideology of the "Russian world." In the context of religious activity, this activity takes the form of distributing relevant literature in churches, organising pilgrimages to holy sites in Russia accompanied by intense indoctrination, and imposing Russian saints on the Ukrainian congregation (like Tsar Nicholas II). It is also manifested in sacral architecture, with the church using Russian temple style to emphasise the dependence on Moscow. As for social activities, the UOC-MP organises various events to promote Russian history and culture, often propagandistic in nature. An example of such initiatives was the International Film Festival "Cinema Assembly on the Dnieper" organised under the auspices of the UOC-MP, which was only officially cancelled due to the efforts of public activists. ${ }^{48}$

It should be clearly stated that the majority of the UOC-MP is clearly antistate, and its activities harm the Ukrainian interests and promote the ideology of the "Russian world" -Moscow's imperial project in Ukraine. An expression of the dysfunction of the Ukrainian state is the fact that the Russian aggression on

44 “Священик Московського патріархату благословив терориста Гіркіна,” iPress.ua (23 July 2014), https://ipress.ua/news/svyashchenyk_moskovskogo_patriarhatu_blagoslovyv_terorysta_ girkina_foto_76113.html (accessed: 24 September 2020).

45 “Як Києво-Печерська лавра виховувала бойовиків для Гіркіна," Espreso.tv (2 May 2018), https://espreso.tv/article/2018/05/02/yak_kyyevo_pecherska_lavra_vykhovuvala_boyovykiv_dlya_ girkina (accessed: 25 September 2020); “Святогірська лавра переховує УПЦ-МП переховує бойовиків і зброю,” РІСУ - Релігійно-інформаційна служба України (15 January 2018), https:// risu.org.ua/ua/index/all_news/community/terrorism/69711/ (accessed: 26 September 2020).

46 ““Філія “русского міра.' Найгучніші скандали за участю УПЦ МП,” Партія "Національний Корnyс" (15 January 2018), https://nationalcorps.org/flja-34russkogo-mra34-najguchnsh-skandali-za-uchastju-upc-mp/ (accessed: 26 September 2020).

47 Ibid.

48 “Кінофестиваль у Дніпрі під егідою УПЦ МП офіційно скасовано," РІСУ - Релігійноінформаційна служба України (2 February 2020), https://risu.org.ua/ua/index/all_news/community/protests/78752/ (accessed: 27 September 2020). 
the "church front" is very often opposed by the civic society, not by the state government which should be responsible for it. The state of Ukraine, represented by the relevant authorities, should strictly demand loyalty from the UOC-MP, and in case of treason and anti-state activity, it should condemn such acts and the church officials committing them in accordance with the law, ensuring national security.

In the context of the Revolution of Dignity and the Russian-Ukrainian War, a positive impact was made by the two other branches of Ukrainian Orthodoxy (UOC-KP and UAOC), which provided support to the Ukrainian society and the state in the difficult times of Russian aggression. In 2018, they teamed up with the Orthodox Church of Ukraine (OCU), which received the Tomos of Autocephaly from Ecumenical Patriarch Bartholomew. This is a significant event that, in our opinion, will have a positive impact on the development of Ukrainian Orthodoxy (the Kyiv tradition) and will help consolidate the nation and the state as a political project (nation-state).

\section{Conclusions}

The consolidation of the state of Ukraine is a process that involves the society's perception, assimilation, and recognition of the state and the ongoing political changes with the aim of creating as a nation-state. The Ukrainian churches, primarily the UOC-MP, should also be aware of this.

Ukraine should reject, not only theoretically, but also from a practical point of view, the so-called "civilisation paradigm" used by the Kremlin and the ROC to consolidate its domination in Ukraine by imposing the concept of the "Russian world." The civilisation paradigm, underpinning the struggle between the Western and Orthodox civilisations, gives the Russian Federation and the ROC, within the framework of the Moscow-Third Rome concept and imperial policy, the possibility of claiming of the role of the sole leader of the Orthodox world and defender of Orthodox values. They implement this policy by way of interfering in the internal affairs of other states (Georgia, Ukraine, Montenegro, Greece, Bulgaria, and others). In practice, this is aimed at eroding state sovereignty (the Putin Doctrine, as an iteration of the Brezhnev Doctrine).

Conversely, approaching the religious factor based on the principle of political theology makes it possible to use the church in the process of building a nation-state in Ukraine, which is essential for the formation of a strong, democratic, and legal state capable of defending its national interests and countering threats to national security. In addition, this approach makes it possible to consider Orthodoxy as part of the Christian civilisation, in which there is a place for Catholics, Orthodox, and Protestants. This non-conflict approach creates a platform for the cooperation within the Western structures (EU, NATO) of states dominated by various Christian denominations, including the Orthodox (Greece, Bulgaria, Romania). 
Therefore, the Orthodox Church of Ukraine (OCU) and especially the united Ukrainian Orthodoxy under the umbrella of the local Kyiv Patriarchate can become an important factor in the consolidation of Ukraine into a nation-state. Following the example of other Eastern churches, these institutions could advocate for European and Euro-Atlantic integration of Ukraine by promoting values forming part of the European identity (ancient Greek philosophy, Roman law, Christianity).

In the case that the division into two Orthodox structures - the OCU and the UOC-MP - is maintained, the state must take measures to protect national security (the political, cultural, informational, and military dimension) by ensuring the loyalty of the church to the nation-state, above all with regard to the Moscow Patriarchate (UOC-MP), which cannot be allowed to engage in anti-state propaganda and activities, particularly in the period of Russian aggression on Ukraine.

\section{Abstract}

The article analyses the influence of the religious factor on the internal processes of nationstate consolidation in Ukraine and on the causes and consequences of the Russian-Ukrainian conflict. The division of the Ukrainian Orthodoxy into three branches (UAOC, UOC-KP and UOC-MP) did not allow the Church to become a consolidating factor in the formation of a nation-state in independent Ukraine and a generator of social transformation. The situation may change for the better after the creation of the Autocephalous Orthodox Church of Ukraine in 2018.

The Russian Federation and the Moscow Patriarchate (ROC) use the ideology of the "Russian world," the leader of which in Ukraine is the UOC-MP, in order to implement the imperial policy and to establish in Ukraine the dominance of the traditions of the Moscow Church, as one of the significant factors of cultural and religious influence (paradigm of this cynical influence and dominance). In the hybrid war between Russia and Ukraine, the UOC-MP, along with the Russian minority, is used as the so-called "fifth column."

In order to resist the Russian hybrid war waged in the humanitarian and religious domain, Ukraine should accelerate the process of formation of a nation-state and counteract the Russian "humanitarian-religious" aggression with a clear policy of protection of its national interests. The basic condition for the existence of a political nation-state is its recognition and loyalty to it by the structures of the civil society. This problem is acute and urgent in the case of the UOC-MP, and the Ukrainian state should not neglect it, especially in the context of national security.

\section{Bibliography:}

Antúnez J.C., The Role of Religion and Values in Russian Policies: The Case of Hybrid Warfare, https://global-strategy.org/the-role-of-religion-and-values-in-Russian-policies-the-case-ofhybrid-warfare/ (accessed: 25 November 2020).

Bentzen N., "Ukraine: Religion and (geo-)politics Orthodox split weakens Russia's influence," EPRS | European Parliamentary Research Service (February 2019) https://www.europarl. europa.eu/thinktank/en/document.html?reference=EPRS_BRI(2019)635525 (accessed: 25 September 2020). 
Jędraszczak K., "Cerkiew Prawosławna na Ukrainie i w Rosji po 2013 r. wobec wyzwań politycznych, konfliktu rosyjsko-ukraińskiego oraz pytań o granice suwerenności," Przegląd Za-chodni (2018), no. 1, pp. 191-209.

Huntington S., Zderzenie cywilizacji i nowy kształt ładu światowego, Warszawa, 1997.

Kuzio T., “Transition in Post-Communist States: Triple or Quadruple?," Politics, 21 (2001), no. 3, pp. 168-177.

Le Bon G., Psychologia. Rozwój narodów, Nowy Sącz, 1999.

Lipiński W., Religia i Kościół w dziejach Ukrainy, Przemyśl, 1999.

Lyubitseva O., "Research on the geography of religion in Ukraine," Peregrinus Cracoviensis, 25 (2014), no. 3, pp. 91-100.

Michalak R., "Polityka wyznaniowa. Zakres zjawiska," Annales UMCS. Sectio K, 26 (2019), no. 1 , pp. 23-35.

Radziszewska-Szczepaniak D., "Spór o relacje między polityką i religią. Perspektywa filozoficzna," Nurt SVD, 2 (2017), pp. 257-269.

“'Ruski świat' nie oznacza budowania imperium rosyjskiego?, Fronda.pl (8 September 2014), http://www.fronda.pl/a/ruskiego-swiata-nie-oznacza-budowania-imperium-rosyjskiego, 41418.html (accessed: 11 September 2014).

Schmitt C., Politische Theologie, Berlin, 1922.

Weber M., Gospodarka i społeczeństwo. Zarys socjologii rozumujacej, Warszawa, 2002.

Аржаковський А., Розбрат України з Росією: стратегія виходу з піке, Харків, 2015.

Балух В., "Міжконфесійні конфлікти: причини, типологія та шляхи подолання," Релігія та соціум (2016), nо. 3-4.

“Белорусский Экзархат," Официальный портал Белорусской православной Церкви, http:// www.church.by/belorusskiy-ekzarhat/ (accessed: 25 September 2020).

Борозенец Т. , Русский мир и РПЦ (попытка прояснения смыслов), https://www.religion. in.ua/zmi/ukrainian_zmi/6940-russkij-mir-i-rpc-popytka-proyasneniya-smyslov.html (accessed: 2 August 2020).

Гуттенбах Г.Р., “Витоки російського імперіалізму, in: Російський імперіалізм, ed. Т. Гунчак, Київ, 2010.

Дугин А., Основы геополитики. Геополитическое будущее России, Москва, 2000.

“Закон про свободу совісті та релігійні організації," Відомості Верховної Ради УРСР (ВВР) (1991), no. 25, p. 283 (зі змінами та доповненням).

Илларионов А., "Границы «большой, или исторической, России» по В.Путину," Радиостанция «Эхо Москвы» (24 July 2019), https://echo.msk.ru/blog/aillar/2469765-echo/ (accessed: 20 September 2020).

Казанова Х., “Я не вірю в нації, але вірю в силу духа українців,” Дзеркало тижня (15 Мау 2015), https://zn.ua/ukr/amp/columnists/ya-ne-viryu-v-naciyi-ale-viryu-v-silu-duhuukrayinciv-172892_.html (accessed: 20 November 2020).

“Кирило помолився за Януковича і нагородив Бойка з Фірташем," Украӥнська правда (2 October 2011), https://www.pravda.com.ua/news/2011/10/2/6634061/ (accessed: 23 August 2020).

“Кінофестиваль у Дніпрі під егідою УПЦ МП офіційно скасовано," РІСУ - Релігійноінформаційна служба України (2 February 2020), https://risu.org.ua/ua/index/all_news/ community/protests/78752/ (accessed: 27 September 2020).

Колодний A. et al., Історія релігії в Україні, Київ, 1999.

Кочеров С., "Русский мир: проблема определения," Вестник Нижегородского университета им. Н.И. Лобачевского (2014), по. 5, pp. 163-167.

Крамар О., “Влада та іï церква,” Тиждень.иа (14 January 2011), https://tyzhden.ua/Politics/6562 (accessed: 15 November 2020). 
Малашенко А., “Религия в России: политизация и размежевания," Московский Центр Карнеги (3 September 2021), https://carnegie.ru/2012/09/03/ru-pub-49253 (accessed: 23 November 2020).

“Митрополит Онуфрій про війну на Сході,” СПЖ „Союз православных журналистов” (14 July 2015), https://spzh.news/ru/zashhita-very/25719-mitropolit-onufrij-pro-vijnu-naskhodi-o-vojne-v-donbasse (accessed: 24 September 2020).

Національна безпека і оборона (2013), no. 1.

“Обращение Президента Российской Федерации," Kremlin.ru (18 March 2014), http://kremlin.ru/events/president/news/20603 (accessed: 20 November 2021).

Полянцева А., ““Симфония» властей в Византии и России как преемницы Византийской империи," Научный журнал КубГАУ, 118 (2016), no. 4.

“Православие в цифрах: сколько храмов и духовных организаций в РПЦ?, ГРОШ ЖУРНАЛ (29 Мау 2019), https://grosh-blog.ru/pravoslavie-v-cifrah-skolko-v-hramov-iduhovnyh-organizacij-u-rpc/ (accessed: 24 September 2020).

Православная Церковь Молдовы, https://ru.mitropolia.md/ (accessed: 25 September 2020).

Путин В., “Россия: национальный вопрос," Независимая газета (23 January 2012), http:// www.ng.ru/politics/2012-01-23/1_national.html (accessed 24 January 2020).

“Интервью Оливеру Стоуну," Kremlin.ru (19 July 2019), http://kremlin.ru/events/president/ news/61057 (accessed: 24 September 2020).

“Путін нагородив іменним годинником митрополита УПЦ-МП у Криму,” РІCУ Релігійно-інформаційна служба України (17 Мау 2019), https://risu.org.ua/ua/index/ all_news/community/religion_and_policy/75844/(accessed: 23 September 2020).

“Релігієзнавець пояснив, чому УПЦ (МП) не можна залучати до примирення," Cerkvarium. org (25 January 2020), https://cerkvarium.org/publikatsii/monitorynh-zmi/religieznavetspoyasniv-chomu-upts-mp-ne-mozhna-zaluchati-do-primirennya (accessed: 24 August 2020).

Римаренко Ю. (еd.), Мала енциклопедія етнодержавознавство, Київ, 1996.

“Святогірська лавра переховує УПЦ-МП переховує бойовиків і зброю," РІСУ - Релігійноінформаційна служба Украӥни (15 January 2018), https://risu.org.ua/ua/index/all_news/ community/terrorism/69711/ (accessed: 26 September 2020).

“Священик Московського патріархату благословив терориста Гіркіна," iPress.ua (23 July 2014), https://ipress.ua/news/svyashchenyk_moskovskogo_patriarhatu_blagoslovyv_terorysta_girkina_foto_76113.html (accessed: 24 September 2020).

Турчин Я., "Сергій Шелухін про роль Церкви у державотворчих процесах України," Українська начіональна ідея: реалії та перспектива розвитку (2003), no. 14, pp. 82-86.

Українська православна церква (Московський патріархат), http://orthodox.org.ua/ (accessed: 25 September 2020).

Филатов С., “Традиционные религии, «русская цивилизация» и суверенная демократия,” in: Религия и конфликт, ed. А. Малашенко, С. Филатов, Москва 2007.

““Філія “русского міра.' Найгучніші скандали за участю УПЦ МП,” Партія „Національний Kopnyc" (15 January 2018), https://nationalcorps.org/flja-34russkogo-mra34-najguchnshskandali-za-uchastju-upc-mp/ (accessed: 26 September 2020).

Юраш А., "В УПЦ МП йде боротьба між проросійськими і проукраїнськими групами, які хочуть бачити свого кандидата на чолі церкви," UkrMedia iнmернет-газета, https://ukr.media/206732/ (accessed: 20 August 2020).

“Як Києво-Печерська лавра виховувала бойовиків для Гіркіна," Espreso.tv (2 May 2018), https://espreso.tv/article/2018/05/02/yak_kyyevo_pecherska_lavra_vykhovuvala_boyovykiv_dlya_girkina (accessed: 25 September 2020).

Яцишин У., “Роль церкви і духовенства у виборчому процесі України," Украӥнська національна ідея: реалії та перспективи розвитку (2011), по. 23, pp. 128-133. 
Walenty Baluk, prof. dr hab. in political sciences, professor at the Faculty of Political Science and Journalism, Maria Curie-Skłodowska University in Lublin. His academic interests include foreign and security policy of Ukraine, Russia, Belarus, Moldova; post-Soviet conflicts; Central and Eastern European geopolitical research; ethnic politics and political systems in Eastern Europe.

(baluk@wp.pl)

Mykola Doroshko, dr in political sciences, academic worker. Head of the Department of International Regional Studies, Institute of International Relations, Taras Shevchenko National University of Kyiv. Author of over 190 scientific and methodological works on the history of Ukraine of the twentieth century, international relations, and geography.

Submitted 24.09.2020, accepted 17.03.2021 